\title{
Alleviation of Refugees COVID-19 Pandemic Risks- A Framework for Uncertainty Mitigation
}

\author{
Mohamed Buheji ${ }^{1}$, Bartola Mavrić2 ${ }^{2}$ Godfred Beka ${ }^{3}$, Tulika Chetia Yein ${ }^{4}$ \\ ${ }^{1}$ Founder International Inspiration Economy Project, Bahrain \\ ${ }^{2}$ Department of Tourism Management, Istanbul University, Turkey \\ ${ }^{3}$ Faculty of Integrated Development Studies, Dept of Social Studies Political and historical studies, University of \\ Development Studies, Ghana \\ ${ }^{4}$ Author \& Founder of ONGC Worker's Mahila Samiti, Assam, India \\ Correspondence: Mohamed Buheji, Founder International Inspiration Economy Project, Bahrain.
}
Received: June 5, 2020
Accepted: June 18, 2020
Online Published: June 22, 2020
doi:10.5539/ibr.v13n7p69
URL: https://doi.org/10.5539/ibr.v13n7p69

\begin{abstract}
The impact of COVID-19 pandemic on the refugees has been a global concern where the possibility of its impact on the total life and livelihood is expected to be tremendous; unless drastic intervention programs are deployed in time of disaster. This paper explores the three largest most vulnerable refugee groups facing the pandemic of COVID-19. The work was approached from a multidisciplinary perspective with the aim of observing the topic from various mindsets such as economy, social science, history, and culture so that a holistic solution can be proposed.

Refugees' variables of uncertainty are examined during both the literature review and the case study. Then the formula of uncertainty is developed, based on the synthesis of both the cases and literature. The uncertainty is then mitigated and eliminated while talking about the risks of the COVID-19, and its potential spread. Finally, a generic framework is proposed so that the refugees not only are protected, but believe that they can have alternative solutions as they come out of the crisis. The paper brings in lots of implications to the international funding agencies, the refugees hosting countries and the local NGOs in the ground; beside the refugees themselves.
\end{abstract}

Keywords: refugee crisis, COVID-19, multidisciplinary review, pandemic impact, Syrian refugees, Afghanistan refugees, Rohingya refugees, uncertainty, resilient models

\section{Introduction}

The COVID-19 pandemic has affected countries globally, raising their concern from a health perspective to great socio-economic impact and variety of spillovers. The escalation of the pandemic influenced many of the marginalised communities, including the poor, the migrants, and the refugees. For refugees, the COVID-19 effect such as lockdown has raised their misery in both life and livelihood. According to The UN Refugee Agency, there are 71 million people involuntary moved from their country of origin, as a result of political conflicts, violence, or human rights violations (UNHCR, The UN Refugee Agency , 2019). There are also 37,000 refugees who are forced to flee their home, on a daily basis. Over two-thirds of the world refugees are today from: Syria, Afghanistan, South Sudan, Myanmar and Somalia. Volkin (2020), Abraham (2013).

This paper aims to exploit what the most vulnerable refugee groups are facing during the pandemic by comparing their lives and wellbeing, before and after the emergence of the COVID-19. The research starts with defining the phenomenon of refugees and what are the worries on these refugees during the COVID-19 pandemic and other potential national and international emergencies. The displacement of the refugees is reviewed too as a challenge during times of lockdown and social distancing. Then, the literature explores how to reduce the refugees' uncertainty during pandemics. One approach for uncertainty reduction and which build more independent models is the refugees' self-sufficiency program. Then, the researchers review how the global refugees' challenges during the COVID-19 pandemic could be a source for a breakthrough solution with the holistic multidisciplinary approach. Volkin (2020). 
This paper proposes adopting a formula that would measure the socio-economic impact on refugees during crisis such as the COVID-19 pandemic. A proposed framework to mitigate the risks in refugees' camps is also presented as part of the findings. The authors propose more work to be done towards developing tools and formulas that would minimise the 'variables of the uncertainty' that are keeping the refugees at risks and stress.

\section{Literature Review}

\subsection{Definition of the Phenomenon of Refugees}

A refugee is someone who had to flee from the country of origin due to different causes of fear due to the person being persecuted on specific grounds (such as race, religion, nationality, membership of a particular social group or political opinion) and is unable or unwilling to seek protection from the State of origin. The person would be granted "refugee status" in a host country, Baloch (2007). However, the refugee definition does not cover every situation where a person is escaping from a dangerous situation, only when the person fears "persecution." Sometimes people would not be given a refugee status if they couldn't prove the fear of natural disasters, climate change, extreme poverty, domestic violence epidemics or health conditions.

The phenomena of refugees have been long in history. However, this terminology has been confused due to socio-political issues. A refugee can be internally displaced person, an asylum seeker, but they differ legally and thus the recognition of rights.

The real reasons for the displacement of the refugees vary; however, all the causes lead to human displacement. Recently, many studies focused on a comprehensive approach in addressing the issue of refugees, so that more we understand their issues the more the role of the international agencies that are entrusted to protect them could be effectively defined. Sometimes a refugee would be internally displaced forced or obliged to flee or to leave their homes or places of habitual residence, but did not cross an internationally recognised country border. The internal displacement would be based on armed conflict, situations of generalised violence, violations of human rights, or natural or human-made disasters.

In some regional contexts, however, the definition of a refugee is broader. In Africa for example, the definition of refugees extends to persons fleeing "events seriously disturbing public order", a very broad category that can also encompass climate change, natural disasters, epidemics, generalised violence and other situations. The 1969 OAU Convention Governing the Specific Aspects of Refugee Problems in Africa is the oldest regional instrument of refugee protection, as it offers legal protection to a wider category of people.

Sometimes the refugees can be asylum seekers who might seek refugee status but who has not yet had a claim settled by a host country. As a result, every refugee starts out as an asylum seeker, but not every asylum seeker will end up being formally granted refugee status. Being a refugee means the person is protected by several provisions under international law, primarily the 1951 Refugee Convention, which covers such issues as a refugee's right not to be returned to the country of origin. Root (2020), Zimmermann et al. (2011).

It is a common belief that the majority of refugees are hosted in developed countries, such as European countries or the US. However, $85 \%$ of refugees are actually hosted in developing countries. This makes them more vulnerable, especially in times of conflicts, disasters and national/international emergencies, similar to the latest COVID-19 pandemic. Countries as Turkey, Uganda, Pakistan, Lebanon and Iran are all considered some of the top refugee-hosts. To get an idea of the proportions, by the middle of 2018, Turkey hosted 3.6 million refugees while the rest of Europe hosted about 2.7 million. Regarding the country of origin, it is estimated that $57 \%$ of refugees worldwide are coming from just three countries: Syria, Afghanistan and South Sudan. Baloch (2007).

The main reasons why we are witnessing refugee even in the $21^{\text {st }}$ century is the increase in civil wars, armed conflicts, religious persecution, which the Rohingya Muslim is a good example for. Nowadays, also we started to see refugees due to forced migration generated by climate change or natural disasters, even though "climate refugees" are not considered grounds to grant refugee status as per the UN yet.

\subsection{The Worries on Refugees during Pandemics}

During pandemics, the extreme national spirit raises in any community. All those who are considered expats or even those came to work as labour inside the country, or forced to refuge or to be displaced would be considered a burden on the health system and even as a source of threat to the country. Besides the refugees' day to day hardship, the threat of attacks and violence the consequences of the COVID-19 whether the requirements of the social distancing and the lockdown support by curfew decreased there for securing even their day to day minimum food and shelter requirements. Volkin (2020), Root (2020). 
The other challenges that came with the pandemic are caused by the confined spaces and the areas where the refugee camps are usually hosted. For example, certain camps are hosted in areas where drainage, waste all collected. During the month of monsoon where heavy rains lead to landslides, waterlogging and heavy winds in Cox's Bazar, Bangladesh, one million Rohingya refugees are usually affected in a very tight area and camps. These types of risks are exacerbated during the pandemic, and when refugees are hosted in developing countries that do not have the resources to provide the necessary aid to large numbers of refugees. Another relevant challenge faced by refugees is reaching the destination country. Sometimes geography presents a major challenge. Refugee boats are often overcrowded and in poor condition. Baloch (2007).

Despite the transmission rate in each country differ, the refugees' risk of contracting and transmitting the virus might be more than the local populations because they live in very tight heavily populated areas, besides what mentioned earlier that over $80 \%$ of these refugees and the displaced people are hosted in low to middle-income countries, which have weaker health and water and sanitation systems.

Furthermore, the major worries on the refugees during the highly contagious COVID-19 pandemic comes from the limited funding of the United Nations High Commissioner for Refugees (UNHCR), who have limited resources for a global emergency as pandemics and would need both WHO help and the host of the country to ensure effective mitigation and treatment program are mandated. Despite there are also recently announced programs that work to compact the challenges of refugees, this response to large-scale remains inadequate and underfunded. Root (2020).

\subsection{The Challenge of Refugees Uncertainty during Pandemics}

One could understand the amount of refugees uncertainty if he/she go back to the definition of a 'Refugee' from UNHR (United Nation Human Right Council); as someone who has been forced to flee from his/her original country because of persecution, war or violence.ost likely, they cannot return home or are afraid to do so and leading to causes that make refugees fleeing their countries. UNHR further species that Two-third of all the displaced refugees worldwide come from just five countries namely: Syria, Afghanistan, South Sudan, Myanmar and Somalia. The causes behind the refugees' displacement are highly related to life more than a livelihood. Thus the estimated 258 million people (UN, 2017) need to be reshaped to build a balance that they can maintain both life and livelihood.

The consistent displacement of the refugees is often determined by the 'Pull vs Push' factors. These factors in themselves are sources of uncertainty, and thus lots of stress and mental health issues. If the country they try to seek asylum at, have 'pull factors' as better standards of living such as higher wages, or economic incentives for low and middle class, or better working conditions, or have success stories of previous migrants then the country would have many refugees that would try to reach it, EUROSTAT (2000). Therefore, the concern would lie about the stabilising of the irregular movements of the refugees during the COVID-19 and similar pandemics so that they would be given the proper care into the territory they last arrived at even if they don't carry sufficient documentation. Volkin (2020), Root (2020).

Refugees uncertainty increases with their uncertain situation in which they find themselves, feel impelled to move from one country to another in an irregular manner, besides not knowing what would happen to them next day, based on the fund and the hosting country. Therefore, it highly important that they feel not only protected, but believe that they are supported, with durable solutions that would reduce their vulnerability over time.

\subsection{Importance of Refugees Self-Sufficiency Program}

To address these worries the UN and other leading international and national NGOs need to support the refugees to build their own self-sufficiency and give them a type of equity in sharing responsibility, ensuring that host communities get the support needed. It is also aimed at enhancing refugee self-reliance. Such a program would ensure that pandemics, national or international emergencies and disasters won't stress both the refugees or the hosting countries and thus cause deterioration of the settled relations. Also, it would give the refugees the chance to thrive, not just survive, especially if the SF program is supported by a type of recognition, supply chain, education and technical support.

In many refugees camps that relief efforts need to start by visualisation for self-sufficiency in mind, which could start with the provision of the proper utility of water, sanitation, hygiene and healthcare. Hence, while trying to spread the concept of self-sufficiency, an awareness program in the camps relevant to the prevention of the spread of the virus and social isolation can be adopted. 
As thousands of already vulnerable families find themselves amid increasing poverty due to the on-going pandemic and restrictions, UNHCR is working tirelessly to ensure that refugee and displaced families have their basic needs such as shelter, food, water and medicine.

\subsection{Global Refugee Crisis and the Challenges of COVID-19 Pandemic}

The pandemic COVID-19 has spread into already deteriorating conditions of overpopulated refugee camps. Displaced people and host communities are the most threaten as the pandemic COVID-19 spreads. The most vulnerable ones are people situated in refugee camps, with limited access to health care, hygiene necessities and where social distancing is impossible. According to the International Rescue Committee, the health system available to these groups will be overwhelmed with no capacity to handle the COVID-19 outbreak, Volkin (2020), (Root, 2020).

Many have had to flee for safety to other neighbouring countries to begin a new life. Women and children have had to go through the tough times as well making them very vulnerable. For example, the Syrian refugee is the biggest issue after the Second World War, displacing a high number of people leaving them in a vulnerable position. Refugees in Afghanistan have also gone through the worst experience in their lives as their problem is persistent. Buheji and Ahmed (2019b).

The quick spread of the novel coronavirus has made practices like social or physical removing and standard hand-washing a fundamental piece of everyday life. In any case, these measures can be especially hard to try in thickly populated, casual urban settlements mainly the refugee camps where congestion makes the "two-meter division rule" practically difficult to maintain - and where many need accesses to fundamental administrations like water and sanitation, the chances having an outbreak is obvious. MacGregor (2020).

Due to lack of food and other essentials due to the lockdown, there are possibilities of people turning to crime such as robbery. The boats carrying Rohingyas in Malaysia has always made the citizens insecure about the share of their resources. The Rohingyas had to give up on their petty jobs/ways of earning a livelihood in fear of getting infected.

UNHCR, has the mandate to provide international protection to refugees, including promoting the accession to international refugee instruments and other relevant human rights instruments. UNHCR's activities are also focused on assisting in the strengthening of legal structures that would enhance the rule of law, including in the area of transitional justice. But the question here lies how far an international body or a country with refugee camps has been able to cater to the needs of the refugees during this global pandemic. Its high time to strengthen the health system and access funds and other humanitarian aids to the refugees before it gets too late.

The worries of the negative impact of the COVID-19 pandemic still exist till the write up of this paper, however, it is not known yet whether this would carry a short-term or long-term negative impact on already vulnerable groups of refugees. This study found that large numbers of refugees reside illegally in host countries, making it difficult for them to be part of the workforce legally. Accordingly, earning their primary income by daily wages becomes more difficult or nearly impossible with lockdowns. Besides, during the pandemic of COVID-19, the majority of the industries and businesses around the globe stopped operating, leaving many refugees and displaced populations without access to their minimum income. Not to mention, that not being able to be financially independent originates from other challenges affecting the family life, society, and future generations. Volkin (2020).

Refugees often share their shelter with multiple families in very density conditions which make extraordinary difficult to control spreading of COVID-19. The biggest concern is on the Rohingya overpopulated refugee camp located in a dense area in Bangladesh. Moreover, in high risk are those internally displaced, such as people in Darfur, Sudan as well as Idlib, Syria; people displaced internally don't have the same right as refugees because they have been persecuted within the country of origin (Volkin, 2020). Over $80 \%$ of the world's refugees and internally displaced people are hosted in low-income countries. The United Nations stated, by the April 16, 122 refugee host countries reported positive cases of the COVID-19 (UN, Unied Nations , 2020).

\subsection{Understanding the Challenge of Uncertainty}

Buheji and Ahmed (2017) mentioned about the challenge of feeling fearful from a risk especially when it increases the uncertainty about the future. As part of their 'breaking the shield' problem-solving approach they called for (abundance thinking) through focusing on 'what happens from us' not 'what happens to us' and on "what we have" not "what we lack". This mindset as per Buheji and Ahmed would give the communities they kind of assurance and confidence, along with possession of the capacity to create a change through focus and persistence. This type of thinking found to provide the community, especially times of challenges and crisis 
thinking of the need to be engaged and empowered. Buheji and Ahmed (2019a).

In the case of the refugees, the elimination of their uncertainty is the top priority during the crisis as we have seen from the synthesis of the literature review. Only through their engagement, their uncertainty could be reduced. And the more they are involved, the more they could be bringing intrinsic breakthroughs to address many challenges of similar complexity as the pandemic and its impact. Once such communities are encouraged to experiment and explore, they can confront uncertainty and thus become more resilient with more positive thinking and flexible mindset. Buheji (2020).

\section{Methodology}

The top three largest nationalities of the displaced refugee are reviewed from multidisciplinary perspectives. Four scholars of social science, economy, marketing and cultural story-telling experts cover the pandemic impact on the refugees from a different area. Then specific COVID-19 pandemic risk mitigation plans and solutions are customised through a generic framework that would address the mitigation mechanisms in case of similar health emergency or disasters occur.

\subsection{Introduction to the Multidisciplinary Approach}

A multidisciplinary approach was applied to the research topic, which involved the experts from multiple disciplines to redefine the refugees' problem out of normal boundaries. The observations of the topic from various disciplines, such as economy, social science, history, and culture made the impact of COVID-19 pandemic to more holistic which is important to this most vulnerable group, especially for mitigation the risks of this outbreak or preparing for any future health-related pandemic or crisis. The research was done by reviewing the literature by various scholars and researchers published in the academic journals or through media of leading international NGOs working in the field with these refugees.

Due to the lack of literature, data were collected with the help of various non-profit organisations and their continuous updating on the link between the COVID-19 and the refugee crisis. MacGregor (2020).

\subsection{Guiding Question}

The main research question of this multidisciplinary study is "What is the most suitable framework that could be generalised for dealing with the mitigation of risk of a pandemic similar to the COVID-19, taking the most vulnerable refugee camps?"

\subsection{Case Study Design and Criteria}

The review of this particular paper study was based on Interdisciplinary Research (MIR) framework. This method allows us to observe deeper into issues and challenges within multiple disciplines, to answer the main question of the research. The research was conducted in one month using the following electronic database: Scopus. Besides, researchers accessed over 50 published materials by scholars and humanitarian practitioners.

With an empathetic mindset to evaluate the impact of the pandemic COVID-19 on the most vulnerable of today's refugees' camps, the research collection started from electronic data based done independently by each researcher. Moreover, any findings and conflicts were resolved within all reviewers. To that, each reviewed record had to be translated and published in English. The study carried out the systematic analysis of collected records, in which the subject matter was identified according to the topics described in the study. Thus, research was not quality assessed due to the current situation of the COVID-19 and the difficulties of possible field research.

\section{Case Study}

\subsection{Syrian Refugee Crisis and the Challenge of COVID-19}

One of the biggest refugee crises today is the refugees of the Syrian conflict. There are an estimated 4,393,831 refugees from Syria in Canada, Europe, Turkey, Africa and in Syria neighbouring countries, Lebanon and Jordan. (UNHCR, The UN Refugee Agency , 2020). The Syrian conflict has produced the most difficult humanitarian challenge since World War II. There are an estimated 12.2 million people in need of urgent humanitarian assistance, around 3.9 million have fled the country, and several million are internally displaced and with no solution in sight to bring the conflict to an end the numbers of refugees are expected to rise (Najjar, 2015).

According to the UNHCR (2019), Turkey and Lebanon host the highest number of register Syrian refugees. The majority of the refugees are living in the urban areas of the country, with just $8 \%$ of refugees are situated in refugee camps (UNHCR, The UN Refugee Agency , 2019). Moreover, for refugees, there are two main ways of reaching a new host destination: travelling (legally or illegally) to a state asylum seeker, or being recognised as a refugee for resettlement in the destination of first asylum (Ostrand, 2015). Although a high number of Syrian 
refugees to neighbouring countries, many of them decided to find a way toward West European countries, often risking their life by choosing dangerous illegal routes. (UNHCR, The UN Refugee Agency, 2020).

The pandemic of COVID -19 might have serious consequences on many of the Syrian refugees, and especially those are rural areas. Humanitarian organisations are warning the pandemic of COVID-19 will have long term consequences for displaced Syrian refugees due to their type of living. Moreover, the majority of refugees have impoverished basic needs such as food, household and education. The biggest fear is an overpopulated camp where social distancing seems impossible. Ostrand (2015).

According to the Danish Refugee Council, of 867 Syrian refugees' household in Jordan just 3\% have a family member is employed at the moment, compared with the $65 \%$ before the pandemic of COVID-19 (MacGregor, 2020). The COVID -19 in Syria was announced on the $22^{\text {nd }}$ of March, resulting in a first death just a few days later (BBC , 2020). Researching throughout available literature, one can conclude that majority of Syrian refugees share the fear of long term economic consequences, stating that many of them have lost jobs due the pandemic of COVID -19 leaving them in debts they cannot pay, such as household rent. Moreover, there is big fear due to the lack of food resulted by losing income (UNHCR, The UN Refugee Agency, 2020).

Syrian refugees around the globe are already in a vulnerable position needing basic health services, besides food and shelter. The Refugee UN Agency assists Syrian refugees by supplying essential medication and soap, as well as educating them about the COVID - 19 with an aim of reducing the spread among the already vulnerable population (UNHCR, The UN Refugees Agency, 2020).

\subsection{Afghan Refugee Crisis and the Challenge of COVID-19}

The Afghan refugee crisis is one of the oldest refugee crises since the time of the Soviet Union when they invaded Afghanistan in the 1970s. War has been the basic problem in the country, leading to the displacement of many citizens and has equally caused the death of many innocent souls, including children. The war crisis to now seems to not end with the increased rate in the civil war. Abraham (2013) sees that the very long duration of the civil war has caused many injustices on the side of women and children being the victims of war. The country Afghanistan has been ripped off its development due to the war crisis.

According to (Colville, October 1998) in his report, Afghan refugees began fleeing their country in 1978, when fighting broke out between the Afghan communist government and various rural resistance groups who felt they were being invaded. This was the first cause of displacement of many Afghans who had to flee for their lives to other neighbouring countries like Pakistan and Iran. These refugees include women and children whose best option was to leave their home country and start a new life in a foreign country with no assurance of success. According to (colville1998), In 1990, the number of refugees from Afghanistan in Pakistan and Iran were a total of 6.2 billion putting lots of burden on both Pakistan and Iran who had to absorb the stranded refugees into their country. In Pakistan alone, UNHCR spent over 1 billion dollars on Afghanistan refugees since it began its operations in 1979. Colville also reported that the world food program also spent an estimated amount of 800 million dollars. Funds were also generated from other agencies, NGOs and even the Pakistan government. However, the same couldn't have been saying about the Iranian government who were very independent and were not relating well with western donor countries that could have assisted them in taking care of the refugees in their country. Eyvazlu (2018).

The studies show that Iran refugees are facing a very difficult time to maintain their livelihood compared to Pakistan refugees. In Pakistan, Afghan refugees were allowed to own business, have access to health facilities and lived as though they were citizens of Pakistan enjoying equal rights (colville1998). This was a good thing for Afghan refugees. This was a new beginning for them, especially for those who had lost a lot in their home country. During this time, the government of Pakistan were very lenient on them. Enjoying social and economic freedom is not something that one can easily enjoy. This went on till 1995 when funds began to reduce. It was quite the same for the refugees in Iran, in the beginning; they had the chance to be absorbed into some Iranian community. However, the refugees received very subsidised food, health care and education. As time went by, there were a series of the problematic uprising against the refugees. According to Colville, Afghan refugees started going through series of ill-treatment and could no longer enjoy certain rights as before, all because the government had signed a repatriation agreement with UNHCR I 1992 where the refugees should have returned to Afghanistan after three years.

The (UNHCR) 2.5 registered Afghani refugees living in Pakistan and Iran don't well-established health systems in their areas. Many have to work for long hours as labour with very low paid salary and conditions. Many also don't have a source of livelihood. 
As a results of the harsh conditions they are going through, (UNHCR, Afghanistan - Border Monitoring Update), reported in (26, APRIL and in 2, MAY 2020) that the majority of these afghan refugees are returning to Afghanistan and some have attributed their reasons for returning to Afghanistan to the following; fear of covid-19, there are no employment opportunities, the abuse they go through in the hands of state authorities, high cost of living and high cost of rent especially in Iran; they are denied access to health facilities, they are being discriminated on by their local communities, the threat of detention and forced quarantine, final to reunite with their family members in Afghanistan.

The wellbeing of Afghan refugees is largely dependent on the roles played by organisations such as the UNHCR and other countries that provide financial aids to refugees. No country will be prepared enough to host and cater for refugees coming from other countries, especially when that country already has problems. So generally speaking, what Afghan refugees have been going through has been a time bomb waiting to explode. It has gotten to the apex. Iranians and Pakistanis have tried their best, but there isn't enough to share anymore, especially during this COVID-19 era.

\subsection{Rohingya Refugee Crisis and the Challenge of COVID-19}

This paper is an attempt to examine the conditions of Rohingya refugees of Indo-Aryan ethnic group during this Global Pandemic COVID-19 who resides in Rakhine state, Myanmar. The 1982 Burmese citizenship law refused to recognise Rohingya as one of the country's 135 ethnicities, rendering them stateless, restricting their rights to a job, education, marriage, religion and free movement. With no official citizenship, they have no recourse to passports or visas required to avail legal immigration. The illegal presence of Rohingyas are mostly seen in the states of India like Assam, West Bengal and Jammu Kashmir, thousands of them have fled to other South Asian countries including, Malaysia, Indonesia and Philippines. However, the majority escaped to Bangladesh, where there is two official registered refugee camp. Gibben (2017).

Same as Myanmar's legislature doesn't perceive the Rohingya as legitimate residents, Bangladesh also don't accept them too. The administration claims they were brought to Rakhine from Bangladesh during when Myanmar was a British state, and the administration says they are living in Myanmar unlawfully. Gibben (2017).

The virus can get transmitted in Rohingya refugees camps from one person to the other very easily through two ways, one through direct physical contact and the other way is through indirect close contact with COVID-19 patients (through droplets produced as a result of coughing or sneezing of a COVID-19 infected person). Considering the general living characteristics of the Refugee camps where one lacks proper sanitation/ hygiene, where people are bound to share toilets with their neighbours followed by cramped living conditions, the pervasiveness of illnesses, and lack of access to medical care and clean water it seems hard for people to survive and fight against the threat COVID-19 loaming the exposed refugees.

Apart from unpleasant living conditions, the refugees have always been exposed to social problems such as assaults. Natural problems also another source of obstacle that faces the Rohingya during the pandemic where there are social problems besides the devastating natural conditions that irrupts every now and then as the floods in both India and Bangladesh refugee camps. This is beside the outbreak of waterborne diseases; as Cholera which always been reported in these areas.

In about 860,000 Rohingya refugees series of camps, the COVID-19 virus could kill more than 1,600 people easily. The first case of Coronavirus in Bangladesh where most of the Rohingya refugees are located has been reported in Cox' Bazar from a local community person, followed by recoding its first COVID-19 death on March 17. The latest statistical data of infected person from Bangladesh is 13,134 (till 09 May 2020) with 206 deaths and 2,101 recoveries.

We presently see the effect that Covid-19 is having in networks that can "social-distancing," wash hands and approach solid human services frameworks, yet this infection has still pushed them to the edge of total collapse. In the thickly stuffed camps of Cox's Bazar, alternatives of social separating or self-disconnection are remote, with numerous displaced people living in squeezed conditions in improvised asylums made of bamboo and canvas.

Cleanliness practices are not practical when standard hand washing become a luxury since access to clean water is seriously constrained. On average, 40,000 people live in each square kilometre in the camps, if any refugee is infected by this virus, many refugees will die in a short time. There are concerns about the overcrowded Rohingya camps where the virus can spread and have an outbreak within no time.

The Bangladesh government has imposed a lockdown on a southern district, housing more than a million Rohingya Muslims fleeing from Myanmar to prevent the spread of coronavirus. Recent news reports recorded in 
BBC News Asia states an estimated 350,000 displaced people across Myanmar "sitting in the path of public health catastrophe", says rights group Human Rights Watch (HRW). According to a report published by HRW, 130,000 Muslims in the Rakhine state of Myanmar lives in open-air detention camps, where health care facilities are restricted with no access to testing facilities of COVID-19. Any camp is prone to the spread of the virus with one toilet shared by 40 people and one water point accessing by as many as 600 . The situation of the refugees residing in Rakhine got worsen considering the fact that they are subjectively prevented opportunities from securing developments and along these lines unfit to get to general wellbeing regardless of whatever they needed to. Gibben (2017).

Government of Bangladesh and the humanitarian agencies are trying to create inclusion of the Rohingya refugees in the Bangladesh government national response plan to COVID-19, UN (2020). However, there is the constant fear of allowing foreign distributors to enter the refugee camps. Food distribution agencies are thus, developing newer methods to eliminate close person to person contact. The United Nations High Commissioner (UNHCR) have established also isolated camp areas for refugees infected with COVID-19, in temporary isolated areas, until they can be transferred to specially designated isolation units. Rescue, (2020).

The NGO in Bangladesh are trying through student leaders, and celebrated faces (as Bangladesh cricket team player) to support the refugees and spread awareness through social media, raising funds to help the country fight against COVID-19.

\subsection{Best Practices Observed from All the Three Main Camps during the COVID-19 Emergency Response}

There are certain best practices that were carried out by the different NGOs to minimise cross-infection and to eliminate the spread of the COVID-19, such as sharing vital coronavirus information with refugees through our "SignPost" online platforms that can be accessed on a mobile phone, or conducting information sessions to demonstrate best practices in hygiene, hand-washing, communicating symptoms, when to go to report to medical personnel, and when to self-isolate. Rescue, (2020).

Proper hand-washing stations were installed, and then the hand-washing techniques and ways how people can protect themselves were demonstrated in the gathering areas in the camps. Hand-washing stations were installed in the shelters. The health workers were trained on how to use personal protective equipment to keep themselves safe.

Delivering food and medicine to refugees while following heightening safety measures gave lots of hands-on and 'learning by doing' to the youth in the camp. Some camps managed to set up a call-centre for the refugees' problems run by doctors and nurses. The aid workers were trained on how to make surgical face masks and other essential protective equipment with local materials. Hygiene kits distributed for members of the families at higher risk.

The other benefit that the COVID-19 crisis brought to the refugees' camps is the calibre to do a risk and response plan with other aid organisations that might not have health experts available. UN (2020).

\section{Discussion and Conclusion}

As COVID-19 spreads globally, people living in conflict zones as refugees will be hit hardest. In countries like Syria, Yemen, Myanmar, Afghanistan and Iraq, years of violence have weakened health systems and shut down medical facilities, putting millions of people at increased risk. Refugees and displaced people usually tend to have a higher rate of underlying physical and mental health conditions due to the impacts of war, disease and famine, making them more susceptible to be infected to COVID-19.

Refugees do not have the luxury of social distancing, and even the supply of freshwater. Hence, hand-washing stations would be needed if the world wants to reduce the infection.

\subsection{The Formula of the Socio-Economic Impact on Refugees due to COVID-19 Crisis}

This study shows that the most important factor that need to be tackled during any emergency, such as the COVID-19 pandemic, is resolving the issues around the camp reaction and realisation of the importance of taking safety measure during such risky disease. This should start with the reduction of the uncertainty of the socio-economic situation of these refugees. This elimination of uncertainty can be visualised with a problem as COVID-19 since it brings with it also large opportunities. Buheji and Ahmed (2019b); Ulmer and Seeger (2011).

The formula that would increase the refugees' uncertainty about the socio-economic impact during the COVID-19 can be as follows: 


\section{Not Availability of Proper Reaction + Total Dependency of Life and Livelihood on External Agencies + Burden/Threat on the Refugees Host = Highest Uncertainty}

Therefore, in order to reduce or eliminate this uncertainty, we need to re-invent or radically change the possibilities of these inputs.

\section{i.e. We need a formula where the 'variables of the uncertainty' that lead to more risks and stress to be zero.}

Although there is some research conducted on the COVID-19 impact on the displaced population, these particular study advocates that generic refugees risk mitigation framework could be developed and adapted based on understanding this formula. The proposed framework is developed according to eliminating the possibility of the uncertainty, i.e. to prevent long term consequences caused by the pandemic of COVID-19 on this already vulnerable group could bring breakthrough solutions to the refugees and their business model that usually setup to dependent on the external parties.

The multidisciplinary approach used for the development of the framework and the empathetic mindset of the researchers created a pull thinking (i.e. selective thinking) that the pandemic of the COVID-19 might have many opportunities to the development of the refugees and their situation in the camp; beside it might open future development projects. This positive approach has taken into consideration that one of the objectives of the framework should be reducing and preventing long term consequences which will affect daily lives of the displaced population and ease the burden on the host and the host community. Ulmer and Seeger (2011).

\subsection{Proposed Framework to Mitigate the Risks of Refugees Camp from COVID-19}

In order to mitigate the risk from COVID-19 pandemic on the refugees and specifically the risk of the uncertainty, a real-time risk management and response framework is proposed. The framework targets to integrate all the efforts to keep the communities health and safety efforts together and bring the most suitable knowledge to the refugee community while delivering lifesaving care and sources of better livelihood in both the short and long run.

Based on the multidisciplinary review of the three most challenging refugees camps, the authors propose the following framework so that we turn the COVID-19 pandemic risks and problem into an opportunity for the camps to be more resilient. Buheji (2020), Najjar (2015). As safety comes first, the camp youth and internal NGOs need to be engaged on how to react through the process of creating safe-haven for the most vulnerable people in the camp, i.e. the elderly and those suffering chronic disease, as shown Figure (1). The business model of the camps need to be re-invented, to create a level of independence in the model of the camp through starting self-sufficiency programs to produce food, essential items for the refugees and establish a type of sharing economy system between the camps during the crisis. If this model is implemented, the refugees would have more potential to realise how much they can independent from the support of the UN and UNHCR, besides other main NGOs. The authors propose that this can start even from the time when installing hand-washing stations and other COVID-19 response activities or supplies. Believing in these self-made reforms would help to resolve the risk factors from the pandemic and even create a possible flow of pandemic resilient camps. i.e. camps that benefited from the COVID-19 and came out stronger. Najjar (2015).

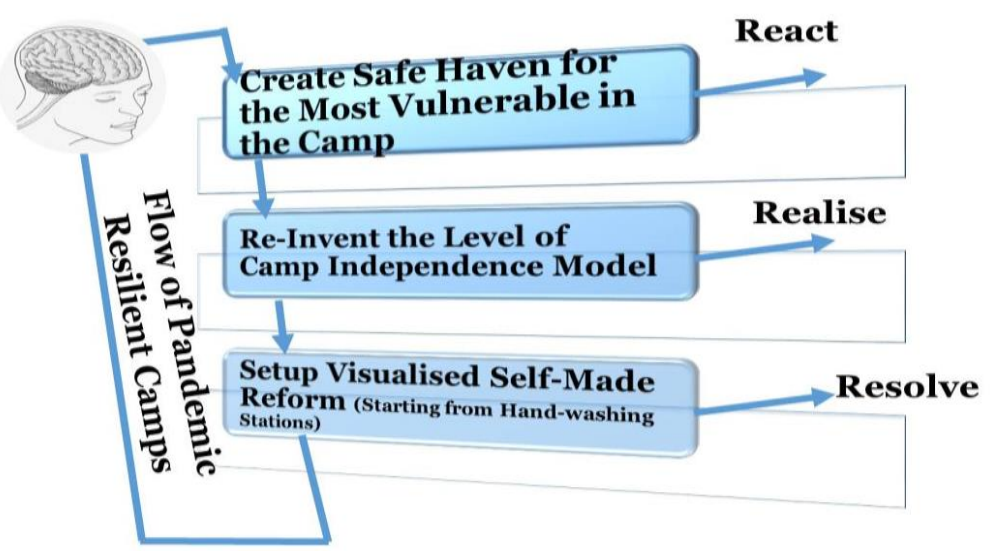

Figure 1. Framework of Flow of Pandemic Resilient Camps that helps to reduce the Refugees Uncertainty 


\subsection{Limitations and Implications of This Study}

The main limitation of this study is that is comes based on the literature review of only the three largest refugees camps and did not cover all the refugees in the world. Thus, it can be generalised yet until it is tested in different countries and implemented fully as a pilot during or after the pandemic.

However, this study carries lots of important implications for the world and the refugees' community. First, it gives a possibility of turning the negative conditions of the refugees' camps in even during one of the most challenging health crisis in the last one century into an opportunity where the business model of the refugees can be more challenged to be made more independent of both the hosting country and the international donors or world NGOs. On the side, this research opens doors for implementing self-sufficiency programs in the different refugees' areas so that they become more independent communities that be self-sustaining and find out new livelihood during and after the crisis. 'Opening a candle is better than cursing the darkness'.

\section{References}

Abraham, R. (2013). The Afghanistan Refugee crisis: implications for Pakistan and Iran. July, 191.

Baloch, A. (2007). The Economic effects of Refugees crises on neighbouring host countries: Emphirical evidence from Pakistan.

BBC. (2020, March 30). Retrieved May 15, 2020, from https://www.bbc.com/news/world-middle-east-52100372

Buheji, M. (2020). Visualising Resilient Communities, Authorhouse Publishing, UK.

Buheji, M., \& Ahmed, D. (2019a). The Defiance - A Socio-Economic Problem Solving. AuthorHouse, UK.

Buheji, M., \& Ahmed, D. (2017). Breaking the Shields. Archway Publishing, USA.

Buheji, M., \& Ahmed, D. (2019b) Framework for Mitigating Coming Socioeconomic Crisis. American Journal of Economic, 9(6), 320-327

Colville, R. (October 1998). Afghan Refugees: Is International Support Draining Away after two decades of exile? Canada's journal on refugees. https://doi.org/10.25071/1920-7336.21975

Eyvazlu, J. S. (2018). Urbanisation, refugees and irregular Migrants in Iran.

EUROSTAT. (2000). Push and Pull Factors of International Migration. Luxemburg: Office for Official Publications of the European Communities.

Gibben, S. (2017). Myanmar's Rohingya Are in Crisis-What You Need to Know. National Geographic, September 9. Retrieved from

https://www.nationalgeographic.com/news/2017/09/rohingya-refugee-crisis-myanmar-burma-spd/

MacGregor, M. (2020. COVID-19 'Crisis on top of a crisis' for refugees, aid group warns. Info Migrants. May 01

Najjar, S. (2015). Regional Refugee \& Resilience Plan 2015 - 16. New York: United Nations Development Programme (UNDP) Publications.

Ostrand, N. (2015). The Syrian Refugee Crisis: A Comparison of Responses by Germany, Sweden, the United States. Journal on Migration and Human Security. https://doi.org/10.1177/233150241500300301

Ulmer, T. L., \& Seeger, S. M. (2011). Effective Crisis Communication: Moving From Crisis to Opportunity. New Delhi: SAGE.

Root, R. (2020). Here What the COVID-19 Response Looks Like in Refugee Camps. Retrieved May 10, 2020, from https://www.devex.com/news/here-s-what-the-covid-19-response-looks-like-in-refugee-camps-96874

UN. (2020). Scaling COVID-19 Response Protect Refugees and Migrants. Retrieved May 10, 2020, from https://www.un.org/en/un-coronavirus-communications-team/un-scaling-covid-19-response-protect-refugee s-and-migrants

UNHCR. (2014). Refugee Protection and Intertational Migration. Geneva: The UN Refugees Agency.

UNHCR. (2019, June 19). The UN Refugee Agency. Retrieved May 10, 2020, from https://www.unhcr.org/en-us/figures-at-a-glance.html

UNHCR. (2019). The UN Refugee Agency. Retrieved May 10, 2020, from https://www.unhcr.org/syria-emergency.html

UNHCR. (2020, May 01). The UN Refugee Agency. Retrieved May 15, 2020, from 
https://www.unhcr.org/news/latest/2020/5/5eabcf704/refugees-across-arab-world-feel-economic-pain-coron avirus.html

UNHCR. (2020, Aprile). The UN Refugee Agency. Retrieved May 10, 2020, from https://data2.unhcr.org/en/situations/syria

UNHCR. (2020). The UN Refugee Agency. Retrieved May 15, 2020, from https://www.unhcr.org/syria-emergency.html

UNHCR. (2020, May). The UN Refugees Agency. Retrieved May 15, 2020, from https://www.un.org/en/un-coronavirus-communications-team/un-scaling-covid-19-response-protect-refugee s-and-migrants UNHCR. (n.d.).

UNHCR. (2018-2019). Solution strategy for Afghan refugees. Enhancing Resilience and co-existance through greater responsibility-sharing.

UNHCR. (2020). ( Afghanistan - Border Monitoring Update - O2May_FINAL, 2020).

UNHCR. (2020). UNHCR Afghanistan - Border Monitoring Update - O2May_FINAL.

UNHCR. (26, APRIL- 2, MAY 2020). Afghanistan - Border Monitoring Update).

Rescue. (2020) Coronavirus Response, Who is Most at Risk from the Coronavirus. Retrieved from https://www.rescue.org/topic/coronavirus-response\#who-is-most-at-risk-from-the-coronavirus

Volkin, S. (2020). How Are Refugees Affected By Covid-19? John Hopkins Magazine, April.

Zimmermann, A., Dörschner, J., \& Machts, F. (2011). The 1951 Convention Relating to the Status of Refugees and Its 1967 Protocol. Oxford: OUP Oxford Press.

https://doi.org/10.1093/actrade/9780199542512.001.0001

\section{Copyrights}

Copyright for this article is retained by the author(s), with first publication rights granted to the journal.

This is an open-access article distributed under the terms and conditions of the Creative Commons Attribution license (http://creativecommons.org/licenses/by/4.0/). 